\title{
Seventy-five Nobel laureates confer at Paris summit
}

\section{Paris}

Aт the invitation of French president François Mitterrand, 75 Nobel laureates gathered in Paris last month for a conference entitled "Facing the 21st Century: Threats and Promises". The conference was the idea of Nobel peace laureate Elie Wiesel, who, paraphrasing Paul Valéry, explained that, "since the future is no longer what it used to be, it is our duty to approach it with caution".

The five themes, each tackled by a separate working group, covered peace and disarmament, human rights, the third world, science and technology and culture and society - themes whose globality sometimes accentuated the frequent association of Nobel awards with anglophone countries of the Northern Hemisphere. Only one Nobel laureate from a 'developing' country was present - physicist Abdus Salam from Pakistan, who now works in Trieste. Similarly, as Wiesel put it, the restriction of Nobel awards to a few disciplines meant that "biologists, doctors and novelists would have to talk about peace - but why not?"

Of the sixteen recommendations presented by Wiesel, two themes dominated: respect for human rights, including the right to education and technology; and the need to attack the polarization between the Northern and Southern Hemispheres perpetuated by the third world debt. The laureates called for an international summit specifically to address what Mitterrand called "the terrible observation" that it is "not the countries of the North which contribute to finance the South, but the reverse".

On disarmament, familiar paradoxes were aired. Although scientists had discovered the principles upon which destructive weapons have been built, responsibility for their deployment belongs to society as a whole. More than one speaker pointed out that whereas the Northern Hemisphere has known 40 years of peace since the bombing of Hiroshima and Nagasaki, continued 'conventional' wars have continued to disrupt the south.

The threat to world health posed by the AIDS (acquired immune deficiency syndrome) pandemic is an issue which many felt crystallize the problems of this fin de siècle and the central role of science in their solution. Joshua Lederberg, pioneer of genetic engineering, pointed out that "it is a pyrrhic victory for a virus to eradicate its host", but admitted that "each individual death of an infected person is a counter-example" to those who believe in natural mitigation. While genetic engineering could be "our most potent means of analysing viruses and developing vaccines", he felt that technological improvements in transport, sanitation and vaccination have paradoxically left us more vulnerable to microbial attack.

It was John Vane, 1982 laureate in physiology or medicine, who brought the search for an AIDS vaccine into the arena of world economics. If a new AIDS therapy is developed, he claimed, it "will not be because pharmaceutical companies want to cure the disease. . . . but because they want to make a profit". Vane called for a truce in competition between companies searching for an AIDS treatment and for a change in legislation, to shift the onus of responsibility from manufacturer to governments if a successful therapy produces toxic side-effects.

Current legislation would only prolong the delay between discovery and commercialization of an effective product, said Vane, who also challenged manufacturers to collaborate on research and to forgo profits. "Treatment with Retrovir currently costs $\$ 200$ per patient per week . . . and

5 million Africans are already infected. Neither they nor their governments could afford to pay for costly treatment."

Aware that the conference could not hope substantially to change world politics, Wiesel felt that "the fact that the conference took place is in itself significant and important". Wiesel's Foundation for Humanity, set up in 1986 with his $\$ 300,000$ prize money, will organize a reunion in two years to study the problems highlighted in Paris.

Peter Coles

\section{Employee accuses Stanford of health and safety violations}

\section{San Francisco}

STANFORD University president Donald Kennedy has called for a university-wide review of health and safety practices, in response to a letter he received on 10 December from a high-ranking employee complaining of wide-ranging safety violations, mismanagement and cover-ups. Aware of the current sensitivity of any questions regarding research safety, Kennedy has arranged for the review to be carried out largely by people from outside Stanford, and has promised to make the results public

The accusations come at a bad time for Stanford, with local distrust of university research running high, especially regarding safety issues. Community opposition to the expansion of research facilities has delayed the occupation of a research building at the University of California at San Francisco (see Nature 328, 626; 1987) as well as the construction of new research and animal buildings at Stanford (see Nature 329, 477; 1987)

Stanford has promised to publish its findings as an act of good faith towards the community - "a lot of short-term pain", said spokesman Bob Beyers, for a potential long-term gain in credibility.

Stanford officials refuse to name the employee who wrote the letter, but local press reports have identified him as an operations manager with the health and safety department, who resigned in December. Press reports have quoted him as saying he was ordered to keep quiet Stanford officials say the investigation will deal also with these charges of cover-up and intimidation.

Kennedy has named a committee of five advisers to help evaluate the review, consisting of former US Secretary of Educa- tion Shirley Hufstedler; Jere Goyan, dean of the school of pharmacy at the University of California at San Francisco and former commissioner of the Food and Drug Administration; Wolfgang Panofsky, former director of the Stanford Linear Accelerator Center; Stanford economics professor Kenneth Arrow, chairman of the Stanford faculty senate; and Victor Calvo, a former state assemblyman for the district including Stanford.

The first phase of the investigation will focus on specific allegations of safety violations in 10 campus buildings. None of the allegations has revealed immediate grave hazards, said Kennedy. Most involve storage of toxic chemicals and potential re-entry of toxic fumes vented through fume hoods. The 10 -member auditing team from Stanford Research Institute's environmental health programme began to interview employees on 11 January, and has promised a preliminary report by the end of the month.

The second phase of the audit, for which a team has not yet been named, will investigate possible management improprieties, including cover-ups and employee intimidation. In a third phase, Kennedy plans to go beyond addressing the complaints in the employee's letter, and will appoint a campus-wide task force to evaluate the entire process by which safety policy is designed and implemented at Stanford searching for flaws that may lead to safety inadequacies. A special focus in this phase of the investigation will be the consideration given to safety when new buildings are being designed, an issue particularly timely as Stanford enters a phase of construction of new research buildings (see Nature 329, 281; 1987).

Marcia Barinaga 